\title{
Deteksi Kanker Prostat dengan Elektroda modifikasi Single-Wire Carbon Nanotubes (SWNT)
}

\author{
Maretty Manik \\ Program Studi Sarjana Farmasi, Fakultas Farmasi, Universitas Padjadjaran \\ *email: maretty17001@mail.unpad.ac.id \\ (Submit 30/7/2019, Revisi 3/8/2019, Diterima 12/8/2019)
}

\begin{abstract}
Abstrak
Kanker prostat merupakan salah satu kanker yang paling umum pada pria dan kejadiannya terus berlanjut meningkat di banyak negara. Deteksi dan penatalaksanaan kanker prostat saat ini telah menjadi salah satu masalah yan menantang dan kontroersial dalam bidang kesehatan. Dalam artikel ini akan dibahas terkait elektroda modifikasi Single-Wire Carbon Nanotubes (SWNT) untuk deteksi kaker prostat.
\end{abstract}

Kata kunci : kanker prostat, elektroda, Single-Wire Carbon Nanotubes

\section{Outline}

- Pendahuluan

- Patofisiologi kanker prostat

- Deteksi kanker prostat

- Mengapa harus digunakan imunosensor?

- Prostate Specific Antigen (PSA)

- Kesimpulan

- Daftar Pustaka

\section{Pendahuluan}

Dibandingkan dengan kanker kulit, kanker prostat merupakan kanker yan paling sering terjadi pada pria di Amerika. Sekitar 1 dari 9 pria akan didiagnosis kanker prostat semasa hidupnya. Kanker prostat ini merupakan penyebab kematian kedua terbesar pada pria Amerika setelah kanker paru.

Kanker prostat bisa menjadi penyakit serius, tetapi kebanyakan pria yang didiagnosis menderita kanker prostat tidak meninggal karenanya. Faktanya, lebih dari 2,9 juta pria di Amerika Serikat yang telah didiagnosis dengan kanker prostat di beberapa titik masih hidup sampai sekarang [1]. 


\section{Patofisiologi kanker prostat}

Kanker prostat berkembang ketika tingkat pembelahan sel dan kematian sel tidak lagi sama, sehingga menyebabkan pertumbuhan tumor yang tidak terkendali. Setelah peristiwa transformasi awal, mutasi lebih lanjut dari banyak gen, termasuk gen untuk p53 dan retinoblastoma, dapat menyebabkan perkembangan tumor dan metastasis. Sebagian besar kanker prostat (95\%) adalah adenokarsinoma [2].

\section{Deteksi kanker prostat}

Deteksi kanker prostat ini dapat dilakukan dengan dua cara yaitu dengan tes DRE (Digital Rectal Exam) atau dengan menggunakan tes darah PSA [3]. Saat ini, uji dengan tes DRE telah jarang dilakukan karena membutuhkan waktu yang jauh lebih lama untuk mendapatkan hasilnya analisa dibandingkan dengan uji PSA. Uji PSA untuk mendeteksi kanker prostat ini menggunakan prinsip imunosensor.

\section{Mengapa harus digunakan imunosensor?}

Karena imunosensor bersifat sangat spesifik yaitu antibodi hanya akan terikat pada antigen tertentu saja, selain itu antibodi spesifik ini memiliki afinitas yang tinggi terhadap antigennya yang berarti ikatan antibodi antigen ini sangat kuat.

Imunosensor merupakan suatu perangkat analitik dimana proses pembentukan kompleks antibodi antigen dideteksi dan dikonversi melalui transduser menjadi sinyal listrik yang dapat diproses, direkam dan ditampilkan [3].

Prinsip imunosensor terbagi menjadi dua kategori, yaitu imunosensor tak berlabel dan imunosensor berlabel. Imunosensor tak berlabel dirancang sedemikian rupa sehingga imunokompleks antigen-antibodi ditentukan secara langsung dengan menentukan perubahan fisik pada alat imunosensor yang disebabkan oleh pembentukan kompleks.

Sebaliknya, imunosensor berlabel secara sensitifitas dapat mendeteksi label yang diberikan terhadap antibodi, biasanya berupa enzim, radioisotop yang kemudian antibodi berlabel ini dapat mengikat suatu antigen. Label ini dapat berupa radioisotop maupun enzim ELISA [3].

\section{Prostate Specific Antigen (PSA)}

Deteksi kanker prostat dengan menggunakan immunosensor tak berlabel dapat dilakukan dengan mendeteksi kadar Prostate Spesific Antigen (PSA) dalam tubuh [4]. PSA merupakan suatu protein protease serin yan diregulasi hormon androgen yang mana berfungsi untuk mengatur kekentalan cairan semen (sperma). PSA yang memasuki sistem sirkulasi akan terikat cepat dengan inhibitor protease yakni a1antichymotrypsin (ACT). PSA akan berada dalam bentuk bebasnya (f-PSA) ketika berada dalam lumen karena diinaktivasi oleh proteolisis. Total PSA, jumlah f-PSA dan PSA/ACT kompleks, akan meningkat pada pasien yang mengidap kanker [4]. 
Uji PSA ini dapat dilakukan dengan berbagai cara, salah satu cara mendeteksi PSA yang telah dikembangkan adalah dengan menggunakan suatu mikroelektroda dengan metoda voltametri elektrokimia [4]. Mikroelektroda ini akan mendeteksi arus yang dihasilkan dari oksidasi tyrosine dan tryptophan pada PSA.

Mikroelektroda yang dimodifikasi dengan Single-Wire Carbon Nanotubes (SWNT) lebih menjanjikan daripada mikroelektrode yang tidak modifikasi karena dapat mendeteksi PSA lebih baik dan memiliki sifat mekanikal yang lebih baik. Hal ini dikarenakan SWNT mempunyai sifat yang dapat membuat elektroda meningkatkan transfer elektronnya. Modifikasi ini juga memiliki rasio aspek yang besar sehingga total area permukaan elektroda menjadi lebih besar. Pengukuran menggunakan alat berbasis elektrokimia ini juga memakan waktu yang jauh lebih cepat daripada uji PSA menggunakan alat pada umumnya [4].

\section{Kesimpulan}

Tingginya prevalensi kanker prostat mengakibatkan meningkatnya keperluan deteksi dini kanker prostat. Berbagai metode telah dikembangkan, deteksi kanker prostat dengan menggunakan immunosensor tak berlabel dapat dilakukan dengan mendeteksi kadar Prostate Spesific Antigen (PSA) dalam tubuh. Mikroelektroda yang dimodifikasi dengan Single-Wire Carbon Nanotubes (SWNT) lebih menjanjikan daripada mikroelektrode yang tidak modifikasi karena dapat mendeteksi PSA lebih baik dan memiliki sifat mekanikal yang lebih baik.

\section{Daftar Pustaka}

1) American Cancer Society. 2019. Key Statistics for Prostate Cancer. Tersedia secara online di https://www.cancer.org/cancer/prostate-cancer/about/keystatistics.html\#references [Diakses pada tanggal 2 Juni 2019].

2) Medscape. 2019. Prostate Cancer. Tersedia secara online di https://emedicine.medscape.com/article/1967731-overview\#a4 [Diakses pada tanggal 2 Juni 2019].

3) Aizawa, Masuo. 1994. Advances in Clinical Chemistry. Yokohama: Department of BlonenglneerIng Tokyo Institute of Technology.

4) Okunno, Jun, Kenzo Maeshashi, Kagan Kerman, Yuzuruu Takamura, Kazuhiko Matsumoto, dan Eiichi Tamiya. 2007. Label-free immunosensor for prostate-specific antigen based on single-walled carbon nanotube array-modified microelectrodes. Biosensors \& Bioelectronics, No. 22: 2377-2381. 